\title{
ANNOTATION
}

\section{THE BENEFITS OF AMATEUR BOXING}

\author{
Dr. J. L. BLONSTEIN \\ 62 Falcon Road, London, S.W.11
}

\begin{abstract}
Aggression is a natural instinct in man. It is inborn and possibly is atavistic. Even small children show this tendency and will attack other children or domestic animals by punching, scratching, spitting or even biting. In a civilised society this aggression is curbed by the parents in the home by education, punishment or deprivation and when the child reaches school age, by the teacher.
\end{abstract}

The boy at school still has this aggressive feeling towards his schoolfellows and when there is no supervision by the teacher, e.g. during playtime, one or more boys may attack another.

These aggressive tendencies must be guided into other channels and into what better channels than sport? The ideal way of getting rid of aggression in boys is by teaching them boxing. In Great Britain boys are taught boxing from the age of 11 . On the Continent the starting age is 14-15. In this sport they have the advantage of physical training and medical supervision before and after their bouts and they are taught self-control, discipline and good sportsmanship.

Boys with poor physique have improved tremendously after 2 years' training - physical training, punch-ball work, shadow-boxing and road-work. We found an average increase of $2^{\prime \prime}(5 \mathrm{cms})$ in height and 7 lbs $(3.18 \mathrm{~kg})$ in weight after 2 years. These benefits have accrued not only from the physical training, but also from the improved diet which has been recommended to the boys and their parents. Stress has been laid on fresh fruits and vegetables, meat, fish, eggs, and milk.

What can be better for a boy's character than to box three rounds with an opponent then shake hands with him and say "Well done!".

That builds character and makes good citizens. Young boxers do not become delinquents, roam the streets or beat up other boys. They are too well-trained and disciplined mentally and physically to rebel against law and order.

Many boys derive psychological benefits from boxing, particularly inadequate, introverted personalities. They develop confidence and become more extrovert.

A schoolboy may only box in eight tournaments during one season (April-October). A schoolboy boxer may also be a member of a Boxing Club, but he is still restricted to eight tournaments suitably spaced in one season. No schoolboy under the age of thirteen may compete in a tournament.

Every young boxer must have a complete medical examination before he is allowed to box. We have found boys who have presented themselves for boxing to have gross medical defects, such as atrial septal defect or kidney disease, and yet they have been playing football or swimming. I say advisedly that boxing is the only sport which gives the participants a complete medical examination, records their activities and injuries and keeps a medical check on them right through their careers.

Each young boxer is provided with a medical record card. This states that he has passed a complete medical examination; all his bouts and injuries are recorded with the recommendation of the medical officer how long he should stay off boxing. The card must be signed by a parent or guardian. Boxing is purely a voluntary effort.

No boxer is allowed to box at any tournament without producing his medical card.

Each boxer must be passed fit by a Medical Officer on the day he boxes, before and after his bout.

Young boxers cannot hurt each other seriously. The boxers of 7 st. and under wear gloves weighing $6 \mathrm{oz}$. $(180.75 \mathrm{gm})$. The boxers of $7 \mathrm{st}$. and over wear gloves weighing $8 \mathrm{oz}$. $(225 \mathrm{gm})$. The recorded number of injuries is about 1 in 200 bouts, that is excluding bleeding noses. Young boxers do not have the strength to inflict a severe blow on their opponent.

On looking through the records I find that there has not been one case of concussion in a schoolboy boxer for the last 9 years (compare this with other games such as football, gymnastics, judo or diving) and there has never been a death in schoolboy boxing (compare this with 4-5 deaths every year at football and 3-4 at cricket).

We made a survey of the top 130 schoolboy boxers reaching the National Semi-finals and we found that they also participated in the following games in this order: 
Association football, swimming, rugby, athletics (field and track), cross country, basketball, cricket, table-tennis, cycling, shooting, horse riding, badminton, judo, tennis, golf, gymnastics, sailing and canoeing

so all their energies were not exhausted by boxing.

A significant percentage also listed art, either in the form of painting or sketching as their chief non-sporting recreational activity. $63 \%$ of the boys had some relative who had boxed.

Many young boxers are able to participate in local, regional and national championships. Some ultimately represent their countries in international boxing. Young boxers broaden their outlook by travelling all over the country for matches and also abroad for inter-city matches.

Boxing is fully justifiable both morally and physically provided it is properly controlled medically.

We are told by the opponents of boxing that boys' intellectual functions are damaged by head injuries. In
London we selected two groups of 100 boys from a Secondary Modern School, at the age of 12, one group being boxers and the others not. We followed their scholastic careers up to the age of 15.

Two educational psychologists carried out I.Q.'s and aptitude tests during this time. Ther $€$ was no appreciable difference between the two groups and actually more boxers went on to the Universities to take up professional careers than the non-boxers. In fact, one schoolboy champion who had over 200 bouts won a Scholarship to Cambridge University, which is an outstanding intellectual attainment.

We also took the E.E.G.'s of 100 youth boxers immediately after their bouts. We found gross changes in the wave patterns in $48 \%$, but all these became normal in 4-6 minutes, thus showing there were no permanent pathological changes.

I would like to sum up by saying that boxing is a real democratic sport bringing together people of all sorts in the very best kind of comradeship; a sound body is essential for a sound mind.

MEDICAL REPORT ON BOXING, COMMONWEALTH GAMES, CHRISTCHURCH

NEW ZEALAND, JANUARY 24th TO FEBRUARY 1st 1974

\author{
J. L. BLONSTEIN, O.B.E. \\ President of the Medical Commission \\ European Amateur Boxing Association
}

There were 155 boxers and 140 bouts (with two walkovers).

The number of injuries compared with similar tournaments was low.

\begin{tabular}{|c|c|c|c|}
\hline \multirow[t]{2}{*}{ Injuries: } & \multirow[t]{2}{*}{ K.O.s } & Round I & $\begin{array}{l}1 \text { unconscious, } 5 \text { seconds. } \\
7 \text { (not unconscious) }\end{array}$ \\
\hline & & Round II & $\begin{array}{l}5 \text { (not unconscious) } \\
1 \text { unconscious, } 10 \text { minutes. Admitted } \\
\text { to hospital overnight. Discharged } \\
\text { satisfactory. }\end{array}$ \\
\hline & Cuts & \multicolumn{2}{|c|}{$\begin{array}{l}\text { left eye, } 3 \text { (stopped) } \\
\text { left eye, } 4 \text { (not stopped) } \\
\text { right eye, } 1 \text { (not stopped) }\end{array}$} \\
\hline & \multicolumn{2}{|c|}{ Abrasions } & 4 (not stopped) \\
\hline & \multicolumn{2}{|c|}{ Haematomata } & 3 (not stopped) \\
\hline & \multicolumn{2}{|c|}{ Sprains } & $\begin{array}{l}\text { one shoulder (not stopped) } \\
\text { one ankle (not stopped) }\end{array}$ \\
\hline & \multicolumn{2}{|c|}{ Nasal injuries } & 1 bruised nose (not stopped) \\
\hline & \multicolumn{3}{|c|}{1 bruising of ribs - not stopped } \\
\hline & \multicolumn{3}{|c|}{1 retired - cut upper left eye-lid } \\
\hline
\end{tabular}

